\title{
THE RELATIVE SUSCEPTIBILITY AND MONITORING OF CITRUS SPECIES / VARIETIES TO CHLOROPHORUS VARIUS Mull. IN CITRUS ORCHARDS IN EGYPT
}

\author{
HASHIM, S. M., A. W. TADROS and EMAN A. ABDEL HAMID
}

Plant Protection Research Institute, ARC, Giza, Egypt.

(Manuscript received 13 September 2013)

\begin{abstract}
The relative susceptibility and monitoring of nine widely spread citrus species / varieties: Navel orange, Balady orange, Valencia orange, grape-fruit, Balady Mandarin, lime, Lemon, Sour orange and Volkamer lemon to the wasp beetle, Chlorophorus varius (Coleoptera: Cerambycidae) borer infestation as well as the population fluctuations were studied at Sharkia governorate, during the three successive years 2010, 2011 and 2012. The mean rate of susceptibility of citrus species and varieties to $C$. varius infestation reached $32.5 \%$ (range, $5.0-55.3 \%$ ). The grand mean degree of susceptibility of citrus species / varieties to $C$. varius infestation approximated 0.6177 beetles / tree / year. Infestation increased from 0.52 beetles / tree at the end of 2010 (one year), to 1.123 beetles / tree at the end of 2011 (two years) to 1.853 beetles / tree at the end of 2012 (three years). Summer months recorded the maximum beetle flight ( 0.3677 beetles), followed by spring ( 0.1241 beetle) and autumn months ( 0.1148 beetles) /tree, but stopped during winter. The grand mean degree of susceptibility of citrus species / varieties to $C$. varius infestation approximated 0.1533 beetles / tree / season. Generally, Navel orange proved to be the most susceptible species followed by Balady orange, Valencia orange, Grape fruit, Mandarin, Lime, Lemon, Sour orange and at last Volkamer Lemon. Infestation increased from 0.13 beetles / tree at the end of 2010 (one year), to 0.28 beetles / tree at the end of 2011 (two years) to 0.46 beetles / tree at the end of 2012 (three years), that impose the need to control this pest in citrus orchards.
\end{abstract}

\section{INTRODUCTION}

In Egypt, citrus ranks first in fruit area and production, as well as is the most economic exporting crop and most favorite popular fruit. Several citrus species and varieties are spread all-over Egyptian Agricultural zones to prolng the harvesting period and accommodate local consumption and exportation. The most widely spread citrus species / varieties could be arranged descendingly as follows: Navel orange (Citrus sinensis), Balady orange ( $C$. sinensis), Valencia orange (C. sinensis), grapefruit (C. paradisi), Mandarin (C. reticulata), lime (C. aurantifolia), Lemon (C. limon), Sour orange (C. aurantium) and Volkamer lemon (C. volkameriana). Chlorophorus varius (Coleoptera: Cerambycidae) is widely distributed all-over the Mediterranean basin area, Europe and Russia (Winkler., 1932; Porta, 1934; Bodenheimer, 1934 and Schmidt, 1962) as well as in Egypt (El-Zoheiry, 1950). Larvae of C. varius feed inside the stem and main branches of trees and cause their death, and the total life cycle 
was completed in almost one year (Tadros, 1993). Frequent field observations indicated that the most important boring pests in citrus orchards are the Coleopterous Cerambycids $C$. varius that attack 21 fruit tree species (Tadros, 1994) and 14 wood and ornamental tree species (Nour, 1963 and Haggag, 1982), Macrotoma palmata also attack citrus trees (Tadros et al., 1993), the Scolytids Hypothenemus eruditus seriously infest sweet lemon, mandarin, lemon and kumquat (Batt et al., 1993), Scolytus amygdale (Tadros, 1994) and the Bostrichid Enneadesmus obtusedentatus (Tadros et al., 1997), as well as the Lepidopterous Cossid Paropta paradoxa was recorded attacking mandarin trees (El-Assal et al., 2008).

Studies on the rate and degree of infestation, seasonal fluctuation of the target pest population, the progress of infestation, the seasonal cycle, and the effect of the main weather factors is essential in successful integrated pest control. However, the literature on the relative susceptibility of citrus species and varieties to borers infestation is lacking allover the world.

The present comparative ecological study is an attempt to contribute to such a gap in the knowledge on the population fluctuation and the relative susceptibility of different citrus species to citrus tree borers. The broad objective of investigation is to gain new information that may help in planning citrus structure system, choice of economic species and varieties and effective "Integrated Control Programs" for the management of tree borers in citrus orchards.

\section{MATERIALS AND METHODS}

The relative susceptibility of the following nine citrus species and varieties, Navel orange, Balady orange, Valencia orange, grape-fruit, Mandarin (Balady), lime, Lemon, Sour orange (Naring) and Volkamer lemon to $C$. varius borer infestation was studied. Infestation studies (rate and degree) were carried out during the three successive seasons 2010, 2011 and 2012 in citrus orchards spread over about 100 feddans area (more than 25 years old) located at Wadi El-Mollak district, Sharkia governorate.

\section{Rate of Infestation:}

The rate of infestation was assessed by the percentage of numbers of infested trees with $C$. varius in each citrus species / variety randomly distributed in the considered citrus orchards each year.

\section{Degree of Infestation:}

The degree of infestation was estimated by the mean number of adult beetles per tree (indicated by the exit holes) that completed their life cycle and emerged from each citrus species / variety in the considered random citrus orchards each year at four time intervales at the end of each season (winter, spring, summer and autumn). At the end of each season, the old counted exit holes were canceled by spray paint. 


\section{Progress of infestation:}

Data of the degree of infestation were accumulated from December $31^{\text {st }} 2010$ until December $31^{\text {st }} 2012$ for each year. The total number of adults represented the accumulated number for the three years together.

Progress of infestation indicated the rate of increase in the borer infestation through advanced years.

The relative susceptibility of the following citrus species and varieties, Navel orange, Balady orange, Valencia orange, grape-fruit, Mandarin (Balady), lime, Lemon, Sour orange (Naring) and Volkamer lemon to $C$. varius were recorded.

\section{RESULTS AND DISCUSSION}

The relative susceptibility to $c$. varius and the population density (rate and degree of population ) on the following nine citrus species and varieties, Navel orange, Balady orange, Valencia orange, grape - fruit, Mandarin (Balady), lime, Lemon, Sour orange (Naring) and Volkamer lemon to the borer were studied.

\section{Rate of $C$, varius Infestation:}

The rate of $C$. varius infestation varied from one citrus species / varieties to another. Navel orange was the most susceptible species to the borer infestation showing $37-78 \%$, with a mean of $55.3 \%$, followed by Balady orange ranging $33-$ $75 \%$, with a mean of $51.3 \%$, Valencia orange showing $29-69 \%$, with a mean of $49 \%$ infestation, Grape fruit ranging $31-58 \%$, with a mean of $43.7 \%$, Mandarin ranging $25-50 \%$, with a mean of $38 \%$. The moderately and least susceptible were Lime (17 - 28\%, with a mean of $22.3 \%)$, Lemon (12 - 22\%, with a mean of $16 \%$ ), Sour orange $(9-15 \%$, with a mean of $11.7 \%$ ), and last Volkamer lemon ( $4-7 \%$, with a mean of $5 \%$ ). The general mean percent of $C$. varius infestation in citrus (species / varieties) orchards ranged from $27.4-36 \%$, with a grand mean of $32.5 \%$.

Table 1. Rate of $C$. varius infestation in citrus species / varieties at Sharkia governorate during 2010, 2011 and 1012 seasons.

\begin{tabular}{|c|l|c|c|c|c|}
\hline \multirow{2}{*}{ No. } & \multirow{2}{*}{ Variety } & \multicolumn{4}{c|}{ Rate of infestation (\%) } \\
\cline { 3 - 6 } 1 & Navel orange & 2010 & 2011 & 2012 & Mean \\
\hline 2 & Balady orange & 78 & 51 & 37 & 55.3 \\
\hline 3 & Valencia orange & 46 & 33 & 75 & 51.3 \\
\hline 4 & Grape fruit & 42 & 31 & 58 & 49 \\
\hline 5 & Mandarin & 25 & 50 & 39 & 38 \\
\hline 6 & Lime & 17 & 22 & 28 & 22.3 \\
\hline 7 & Lemon & 14 & 12 & 22 & 16 \\
\hline 8 & Sour orange & 11 & 15 & 9 & 11.7 \\
\hline 9 & Volkamer lemon & 4 & 4 & 7 & 5 \\
\hline \multicolumn{2}{|l|}{ Total } & 306 & 247 & 324 & 292.3 \\
\hline \multicolumn{2}{l}{ Mean / species or variety } & 34 & 27.4 & 36 & 32.5 \\
\hline
\end{tabular}




\section{The degree of $\boldsymbol{C}$. varius infestation:}

The degree of $C$. varius infestation showed obvious variations among different citrus species / varieties (Tables 2, 3 and 4).

2.1. Navel orange was the most susceptible as the mean number of holes / tree approximated $0.85,1.02$ and 1.15 holes (emerged beetles) / tree / year during the three years of study 2010, 2011 and 2012, respectively. The respective degrees of infestation / tree / month were $0.07,0.09$ and 0.10 holes / tree.

Summer months showed the mean number of emerged beetles, 57, 66 and 71 holes (emerged beetles) / tree during the three years 2010, 2011 and 2012, respectively. Spring months showed less mean number of emerged beetles, 20, 23 and 26 holes (emerged beetles) / tree during the respective three years. Autumn months were the least mean numbers of emerged beetles (holes) / tree were 8,13 and 18 holes / tree during the respective three years. Beetles stopped emergence during winter months. The grand means of emerged beetles / tree / season were $0.21,0.26$ and 0.29 holes during the respective three years.

2.2. Balady orange was also highly susceptible citrus species as the mean number of holes / tree approximated $0.78,0.88$ and 1.14 holes (emerged beetles) / tree / year during the three years of study 2010, 2011 and 2012, respectively. The respective degrees of infestation / month were $0.065,0.07$ and 0.095 holes / tree.

Summer months showed the mean number of emerged beetles, 49, 53 and 68 holes (emerged beetles) / tree during the three studied years 2010, 2011 and 2012 , respectively. Spring months showed less mean number of emerged beetles, 18 , 20 and 22 holes (emerged beetles) / tree during the respective three years. The mean numbers of emerged beetles (holes) / tree in autumn months were 11, 15 and 24 holes / tree during the respective three years. Beetles stopped emergence during winter months. The grand means of emerged beetles / tree / month were $0.20,0.22$ and 0.28 holes during the respective three years.

2.3. Valencia orange was also highly susceptible citrus species as the mean number of holes / tree approximated $0.69,0.80$ and 0.98 holes (emerged beetles) / tree / year during the three years of study 2010, 2011 and 2012, respectively. The respective degrees of infestation / month were $0.06,0.07$ and 0.08 holes / tree.

Summer months showed that the mean numbers of emerged beetles were, 42, 47 and 55 holes (emerged beetles) / tree during the three years 2010, 2011 and 2012, respectively. Spring months showed less mean number of emerged beetles, 17, 18 and 21 holes (emerged beetles) / tree during the respective three years. Autumn months showed also low mean numbers of emerged beetles (holes) / tree reaching 10, 15 and 22 holes / tree during the respective three years. Beetles stopped emergence during winter months. The grand means of emerged beetles / tree / month were $0.17,0.20$ and 0.25 holes during the respective three years. 
2.4. Grape fruit was the relatively highly susceptible citrus species as the mean number of holes / tree approximated $0.64,0.65$ and 0.84 holes (emerged beetles) / tree / year during the three years of study 2010, 2011 and 2012, respectively. The respective degrees of infestation / month were $0.05,0.05$ and 0.07 holes / tree.

Summer months showed that the mean number of emerged beetles were, 39, 39 and 48 holes (emerged beetles) / tree during the three years 2010, 2011 and 2012, respectively. Spring months showed less mean number of emerged beetles, 13, 13 and 18 holes (emerged beetles) / tree during the respective three years. Autumn months showed also low mean numbers of emerged beetles (holes) / tree giving 12 , 13 and 18 holes / tree during the respective three years. Beetles stopped emergence during winter months. The grand means of emerged beetles / tree / month were 0.16 , 0.16 and 0.21 holes during the respective three years.

2.5. Mandarin (Balady) was the higly susceptible citrus species as the mean number of holes / tree approximated $0.52,0.73$ and 0.74 holes (emerged beetles) / tree / year during the three years of study 2010, 2011 and 2012, respectively. The respective degrees of infestation / month were $0.04,0.06$ and 0.06 holes / tree.

Summer months showed the mean number of emerged beetles, 31, 44 and 40 holes (emerged beetles) / tree during the three years 2010, 2011 and 2012, respectively. Spring months showed less mean number of emerged beetles, 10, 15 and 19 holes (emerged beetles) / tree during the respective three years. Autumn months showed the least mean numbers of emerged beetles (holes) / tree showing 11,14 and 15 holes / tree during the respective three years. Beetles stopped emergence during winter months. The grand means of emerged beetles / tree / month were $0.13,0.18$ and 0.185 holes during the respective three years.

2.6. Lime was the higly susceptible citrus species as the mean number of holes / tree approximated $0.47,0.56$ and 0.75 holes (emerged beetles) / tree / year during the three years of study 2010, 2011 and 2012, respectively. The respective degrees of infestation / month were $0.04,0.04$ and 0.06 holes / tree.

Summer months showed that the mean number of emerged beetles were, 29, 35 and 43 holes (emerged beetles) / tree during the three years 2010, 2011 and 2012, respectively. Autumn months gave the least mean numbers of emerged beetles (holes) / tree were 10,12 and 18 holes / tree during the respective three years. Spring months showed less mean number of emerged beetles, 8, 9 and 14 holes (emerged beetles) / tree during the respective three years. Beetles stopped emergence during winter months. The grand means of emerged beetles / tree / month were $0.12,0.14$ and 0.19 holes during the respective three years.

2.7. Lemon was moderately susceptible citrus species as the mean number of holes / tree approximated 0.35, 0.31 and 0.49 holes (emerged beetles) / tree / year during the three years of study 2010, 2011 and 2012, respectively. The respective 
degrees of infestation / month were $0.03,0.03$ and 0.04 holes / tree.

Summer months showed that the mean number of emerged beetles were, 23, 27 and 30 holes (emerged beetles) / tree during the three years 2010, 2011 and 2012, respectively. Autumn months showed lower mean numbers of emerged beetles (holes) / tree were 7,8 and 11 holes / tree during the respective three years. Spring months showed less mean number of emerged beetles, 5, 6 and 8 holes (emerged beetles) / tree during the respective three years. Beetles stopped emergence during winter months. The grand means of emerged beetles / tree / month were 0.09, 0.08 and 0.12 holes during the respective three years.

2.8. Sour orange (Naring) was the less susceptible citrus species as the mean number of holes / tree approximated $0.25,0.27$ and 0.33 holes (emerged beetles) / tree / year during the three years of study 2010, 2011 and 2012, respectively. The respective degrees of infestation / month were $0.02,0.02$ and 0.03 holes / tree.

Summer months showed that the mean number of emerged beetles were, 18 , 19 and 22 holes (emerged beetles) / tree during the three years 2010, 2011 and 2012, respectively. Autumn months showed lower mean numbers of emerged beetles (holes) / tree were 4, 6 and 8 holes / tree during the respective three years. Spring months showed the least mean number of emerged beetles, 3, 2 and 3 holes (emerged beetles) / tree during the respective three years. Beetles stopped emergence during winter months. The grand means of emerged beetles / tree / month were $0.06,0.07$ and 0.08 holes during the respective three years.

2.9. Volkamer lemon was the least susceptible citrus species as the mean number of holes / tree approximated $0.10,0.11$ and 0.15 holes (emerged beetles) / tree / year during the three years of study 2010, 2011 and 2012, respectively. The respective degrees of infestation / month were $0.008,0.01$ and 0.01 holes / tree.

Summer months showed that the mean number of emerged beetles were, 7, 8 and 10 holes (emerged beetles) / tree during the three years 2010, 2011 and 2012, respectively. Autumn months showed lower mean numbers of emerged beetles (holes) / tree were 2, 2 and 3 holes / tree during the respective three years. Spring months showed the least mean number of emerged beetles, 1, 1 and 2 holes (emerged beetles) / tree during the respective three years. Beetles stopped emergence during winter months. The grand means of emerged beetles / tree / month were $0.025,0.03$ and 0.04 holes during the respective three years. 
Table 2. Mean number of $C$. varius beetles in Navel orange (Nav), Balady orange (Bal), Valencia orange (Val), Grape-fruit (G-f), Mandarin (Man), Lime (Lim), Lemon (Lem), Sour orange (S-o) and Volkamer Lemon (V-m) citrus orchards, at Sharkia governorate during 2010 seasons.

\begin{tabular}{|c|c|c|c|c|c|c|c|c|c|c|}
\hline \multirow{2}{*}{$\begin{array}{c}\text { Date of } \\
\text { inspection }\end{array}$} & \multicolumn{10}{|c|}{ Mean no. of beetles $\backslash 100$ trees } \\
\hline & Nav & Bal & Val & G-f & Mnd & Lim & Lem & S-O & $\mathrm{V}-\mathrm{m}$ & Mean \\
\hline $\begin{array}{c}\text { Winter } \\
\text { (Jan. - Mar.) }\end{array}$ & 0 & 0 & 0 & 0 & 0 & 0 & 0 & 0 & 0 & 0 \\
\hline $\begin{array}{c}\text { Spring } \\
\text { (Apr. - Jun.) }\end{array}$ & 20 & 18 & 17 & 13 & 10 & 8 & 5 & 3 & 1 & 10.55 \\
\hline $\begin{array}{c}\text { Summer } \\
\text { (Jul. - Sept.) }\end{array}$ & 57 & 49 & 42 & 39 & 31 & 29 & 23 & 18 & 7 & 32.77 \\
\hline $\begin{array}{c}\text { Autumn } \\
\text { (Oct. - Dec.) }\end{array}$ & 8 & 11 & 10 & 12 & 11 & 10 & 7 & 4 & 2 & 8.33 \\
\hline Grand Total (GM) & 85 & 78 & 69 & 64 & 52 & 47 & 35 & 25 & 10 & 51.65 \\
\hline GM / tree/year & 0.85 & 0.78 & 0.69 & 0.64 & 0.52 & 0.47 & 0.35 & 0.25 & 0.10 & 0.52 \\
\hline GM / tree/ season & 0.21 & 0.20 & 0.17 & 0.16 & 0.13 & 0.12 & 0.09 & 0.06 & 0.025 & 0.13 \\
\hline GM / tree/ month & 0.07 & 0.065 & 0.06 & 0.05 & 0.04 & 0.04 & 0.03 & 0.02 & 0.008 & 0.043 \\
\hline
\end{tabular}

Table 3. Mean number of $C$. varius beetles in Navel orange (Nav), Balady orange (Bal), Valencia orange (Val), Grape-fruit (G-f), Mandarin (Man), Lime (Lim), Lemon (Lem), Sour orange (S-o) and Volkamer Lemon (V-m) citrus orchards, at Sharkia governorate during 2011 seasons.

\begin{tabular}{|c|c|c|c|c|c|c|c|c|c|c|}
\hline \multirow{2}{*}{$\begin{array}{c}\text { Date of } \\
\text { inspection }\end{array}$} & Nav & Bal & Val & G-f & Mnd & Lim & Lem & S-o & V-m & Mean \\
\hline $\begin{array}{c}\text { Winter } \\
\text { (Jan. - Mar.) }\end{array}$ & 0 & 0 & 0 & 0 & 0 & 0 & 0 & 0 & 0 & 0 \\
\hline $\begin{array}{c}\text { Spring } \\
\text { (Apr. - Jun.) }\end{array}$ & 23 & 20 & 18 & 13 & 15 & 9 & 6 & 2 & 1 & 11.89 \\
\hline $\begin{array}{c}\text { Summer } \\
\text { (Jul. - Sept.) }\end{array}$ & 66 & 53 & 47 & 39 & 44 & 35 & 27 & 19 & 8 & 37.55 \\
\hline $\begin{array}{c}\text { Autumn } \\
\text { (Oct. - Dec.) }\end{array}$ & 13 & 15 & 15 & 13 & 14 & 12 & 8 & 6 & 2 & 10.89 \\
\hline $\begin{array}{c}\text { Grand Total (GM) } \\
\text { GM / tree/year }\end{array}$ & 102 & 88 & 80 & 65 & 73 & 56 & 41 & 27 & 11 & 60.33 \\
\hline GM / tree/ season & 0.26 & 0.22 & 0.20 & 0.16 & 0.18 & 0.14 & 0.08 & 0.07 & 0.03 & 0.15 \\
\hline GM / tree/ month & 0.09 & 0.07 & 0.07 & 0.05 & 0.06 & 0.04 & 0.03 & 0.02 & 0.01 & 0.05 \\
\hline
\end{tabular}


Table 4. Mean number of $C$. varius beetles in Navel orange (Nav), Balady orange (Bal), Valencia orange (Val), Grape-fruit (G-f), Mandarin (Man), Lime (Lim), Lemon (Lem), Sour orange (S-o) and Volkamer Lemon (V-m) citrus orchards, at Sharkia governorate during 2012 seasons.

\begin{tabular}{|c|c|c|c|c|c|c|c|c|c|c|}
\hline \multirow{2}{*}{$\begin{array}{c}\text { Date of } \\
\text { inspection }\end{array}$} & \multicolumn{10}{|c|}{ Mean no. of beetles $\backslash 100$ trees } \\
\cline { 2 - 12 } & Nav & Bal & Val & G-f & Mnd & Lim & Lem & S-o & V-m & Mean \\
\hline $\begin{array}{c}\text { Winter } \\
\text { (Jan. - Mar.) }\end{array}$ & 0 & 0 & 0 & 0 & 0 & 0 & 0 & 0 & 0 & 0 \\
\hline $\begin{array}{c}\text { Spring } \\
\text { (Apr. - Jun.) }\end{array}$ & 26 & 22 & 21 & 18 & 19 & 14 & 8 & 3 & 2 & 14.78 \\
\hline $\begin{array}{c}\text { Summer } \\
\text { (Jul. - Sept.) }\end{array}$ & 71 & 68 & 55 & 48 & 40 & 43 & 30 & 22 & 10 & 40.00 \\
\hline $\begin{array}{c}\text { Autumn } \\
\text { (Oct. - Dec.) }\end{array}$ & 18 & 24 & 22 & 18 & 15 & 18 & 11 & 8 & 3 & 15.22 \\
\hline Grand Total (GM) & 115 & 114 & 98 & 84 & 74 & 75 & 49 & 33 & 15 & 73.0 \\
\hline GM / tree/year & 1.15 & 1.14 & 0.98 & 0.84 & 0.74 & 0.75 & 0.49 & 0.33 & 0.15 & 0.73 \\
\hline GM / tree/ season & 0.29 & 0.28 & 0.25 & 0.21 & 0.185 & 0.19 & 0.12 & 0.08 & 0.04 & 0.18 \\
\hline GM / tree/ month & 0.10 & 0.095 & 0.08 & 0.07 & 0.06 & 0.06 & 0.04 & 0.03 & 0.01 & 0.06 \\
\hline
\end{tabular}

Table 5. Progressive mean number of $C$. varius beetles in citrus (in Navel orange, Balady orange, Valencia orange, Grape-fruit (G-f), Mandarin, Lime, Lemon, Sour orange and Volkamer Lemon) orchards, at Sharkia governorate during 2010, 2011 and 2012 seasons.

\begin{tabular}{|c|c|c|c|c|c|}
\hline \multirow{2}{*}{$\begin{array}{c}\text { Date of } \\
\text { inspection }\end{array}$} & 2010 & 2011 & $\begin{array}{c}\text { Sum of two } \\
\text { successive } \\
\text { years }\end{array}$ & 2012 & $\begin{array}{c}\text { Sum of three } \\
\text { successive } \\
\text { years }\end{array}$ \\
\cline { 2 - 6 } & 0 & 0 & 0 & 0 & 0 \\
\hline $\begin{array}{c}\text { Winter } \\
\text { (Jan. - Mar.) }\end{array}$ & 0.1055 & 0.1189 & 0.2244 & 0.1478 & 0.3722 \\
\hline $\begin{array}{c}\text { Spring } \\
\text { (Apr. - Jun.) }\end{array}$ & 0.3277 & 0.3755 & 0.7032 & 0.4000 & 1.1032 \\
\hline $\begin{array}{c}\text { Summer } \\
\text { (Jul. - Sept.) }\end{array}$ & 0.0833 & 0.1089 & 0.1922 & 0.1522 & 0.3444 \\
\hline $\begin{array}{c}\text { Autumn } \\
\text { (Oct. - Dec.) }\end{array}$ & 0.52 & 0.603 & 1.123 & 0.73 & 1.853 \\
\hline GM / tree/year & 0.13 & 0.15 & 0.28 & 0.18 & 0.46 \\
\hline $\begin{array}{c}\text { GM / tree/ } \\
\text { season }\end{array}$ & 0.043 & 0.05 & 0.093 & 0.06 & 0.153 \\
\hline $\begin{array}{c}\text { GM / tree/ } \\
\text { month }\end{array}$ & & & & & \\
\hline
\end{tabular}

\section{Progress of infestation:}

Infestation in citrus species / varieties (Navel orange, Balady orange, Valencia orange, Grape fruit, Mandarin, Lime, Lemon, Sour orange and Volkamer Lemon) increased from one year to another (Table, 5).

Generally, infestation slightly increased from 0.52 to 0.603 after one year (2010 or 2011), to 1.123 beetles (exit holes) / tree after two successive years (at the end of 2011), and increased three times at the end of the third successive year showing 1.853 beetles / tree. 
Seasonally, infestation slightly increased from 0.13 in 2010 or 0.15 in 2011 to 0.28 beetles / tree at the end of 2012 and increased three times at the end of the third year showing 0.46 beetles / tree.

These rapid increases impose the urgent need of control.

\section{Discussion and conclusion:}

The present study affirmed the previous survey and monitoring studies curried out by Tadros et al., 1997 who indicated that C. varius is the dominant and most economically important boring insect pest in several fruit orchards. The current study is unique in determining the relative difference in the susceptibility of local and established foreign species / varieties to the target borer infestation. Monitoring studies (especially the seasonal fluctuation of insect pest population, progress of infestation, seasonal cycle, and effect of the main weather factors on the target pests) are essential in planning successful and effective "Integrated Control Programs" for the management of boring insect pest (Tadros, 1982).

Approximately one/third (32.5\%) of citrus trees were infested with C. varius and obvious differences in susceptibility was noticed between one species / varieties to another ( 5 - 55.5\%). Navel orange, Balady orange, Valencia orange, and Grape fruit, were highly susceptible species ( 43.7 - 55.3 beetles / tree), while Mandarin showed moderate degree of infestation ( $38 \%$ beetles / tree). Lime and Lemon were less susceptible species ( $16-22.3$ beetles / tree). Sour orange and Volkamer Lemon were the least susceptible species ( $5-11.7$ beetles / tree).

The grand mean degree of susceptibility of citrus species / varieties to C. varius infestation approximated 0.6177 beetles / tree / year. Infestation increased from 0.52 beetles / tree at the end of 2010 (one year), to 1.123 beetles / tree at the end of 2011 (two years) to 1.853 beetles / tree at the end of 2012 (three years). Summer months recorded the maximum beetle flight ( 0.3677 beetles), followed by spring ( 0.1241 beetle) or autumn months ( 0.1148 beetles) /tree, and stopped during winter. The grand mean degree of susceptibility of citrus species / varieties to $C$. varius infestation approximated 0.1533 beetles / tree / season. Generally, Navel orange was the most susceptible species followed descendingly by Balady orange, Valencia orange, Grape fruit, Mandarin, Lime, Lemon, Sour orange and at last Volkamer Lemon Infestation increased from 0.13 beetles / tree at the end of 2010 (one year), to 0.28 beetles / tree at the end of 2011 (two years) to 0.46 beetles / tree at the end of 2012 (three years), that impose the need to control this pest in citrus orchards. 


\section{REFERENCES}

1. Batt, A. M., A. M. Okil, S. M. Haggag and G. N. Girgis. 1993. Studies on borers attacking citrus trees in Egypt. Zagazig J. Agric. Res., 20 (11): 395 - 404.

2. Bodenheimer, F. S. 1934. Studies on the ecology of Palestinean Coleoptera: II. Seasonal and diurnal appearance and activity. Bull. Soc. Roy. ent. Egypt, 18: 211-241.

3. El-Assal, M.M.A., M.M. Abdel-Azim and A.W. Tadros. 2008. Monitoring the solitary carpenter worm, Paropta paradoxa (Lepidoptera: Cossidae), recently serious pest in mandarin orchards in Egypt. Egypt. J. Agric. Res., Cairo, Egypt, 17 Feb., 2008.

4. El-Zoheiry, M. S. 1950. The wasp beetle, Chlorophorus varius Mull. (Col.: Cerambycidae) a new pest of grapevine in Egypt. Proc. $8^{\text {th }}$ Int. Cong. ent., Stokholm, pp. 727-731.

5. Fisher, R. A. 1950. Statistical methods for research workers. Oliver and Boyed Ltd., London.

6. Haggag, S. M. 1982. Studies on Chlorophorus varius Mull. (Coleoptera: Cerambycidae). Ph. D. Thesis, Fac. Agric., Al-Azhar Univ.

7. Nour, H. 1963. Classification of wood- boring beetles as known to exist in Egypt, UAR, (Coleoptera). Tech. Bull. 35 pp.

8. Porta, A. 1934. Fauna Coleopterorum Italica. IV. Heteromera-Phytophaga. Piacenza, Stablimento Piacentiono, Italiana: 209-210.

9. Schmidt, G. 1962. A contribution to the occurrence and life-history of Chlorophorus annularis F. (Col.: Cerambycidae). Z. angew. Zool. 49: 87-94.

10. Tadros, A.W. 1982. Biological, Ecological and Control Studies on Paropta paradoxa H. Schaeff. (Lepidoptera: Cossidae) and Chlorophorus varius Mull. (Coleoptera: Cerambycidae) on grapevine trees in Egypt. Ph. D. Thesis, Fac. Agric., Cairo Univ.

11. Tadros, A.W. 1993. The life cycle of the wasp beetle, Chlorophorus varius Mull. (Coleoptera: Cerambycidae) on peach in Egypt. Egypt. J. Agric. Res., 71 (2): 429435.

12. Tadros, A.W. 1994. Monitoring the population of the wasp beetle, Chlorophorus varius Mull. (Coleoptera: Cerambycidae) on peach and its hosts in Egypt. Egypt. J. Agric. Res., 72 (1): 103-115.

13. Tadros, A.W., M.M. Kinawy and F.F. Abd-Allah. 1993. Population dynamics and host range of Macrotoma palmata F. (Coleoptera: Cerambycidae). Insect Science and its Application, Nairobi, Kenya, 14 (5 - 6): 246-354.

14. Tadros, A.W., A.M. Semeada, S.I. El-Sherif and A.A. Fattouh. 1997. Survey of the insect pests in vineyards in Egypt. $7^{\text {th }}$ Nat. Conf. of Pest \& Dis. of Vegetables \& fruits in Egypt, 1997: 242-249.

15. Winkler, A. 1932. Catalogus Coleopterorum regions palaearcticae Dittesgasse II Wie, 18: 1178. 
الحساسية النسبية و التعداد لإصابة أهم أصناف / أنواع الموالح (الحمضيات) بحفار ساق الخوخ ذو القرون الطويلة

Chlorophorus varius (Coleoptera: Cerambycidae) في حدائق الموالح فى مصر

صلاح محروس هاشم ، انطون ولسن تادرس ، إيمان أحمد عبد الحميد

$$
\text { معهة بحوث وقاية النباتات- مركز البحوث الزراعية - دقى - الجيزة- مصر. }
$$

تم دراسة معدل الإصابة (النسبة المئوية لعدد الأثجار المصابة) ودرجة الإصابة (عدد

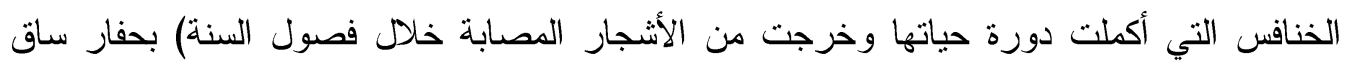

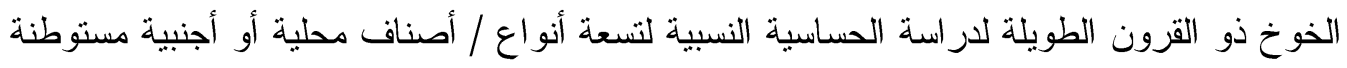

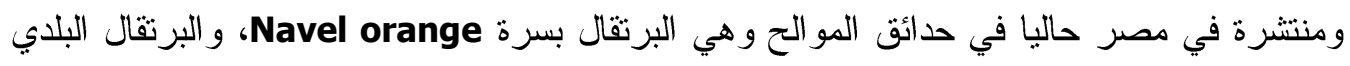
Balady orange، والبرتقال الصيفي Valencia orange، والجريب فروت Grape fruit،

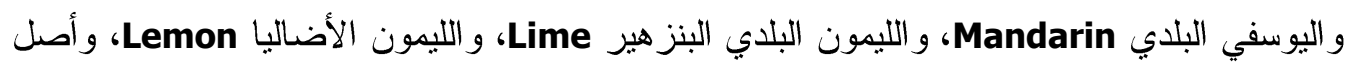

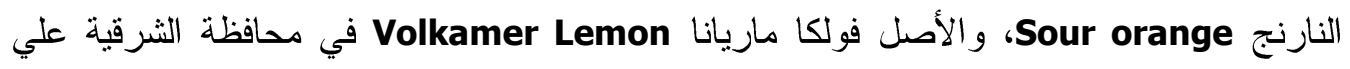

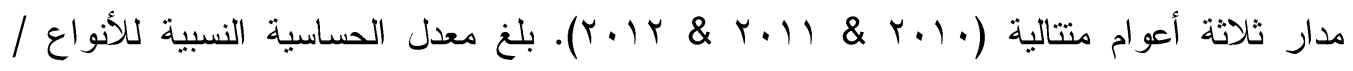

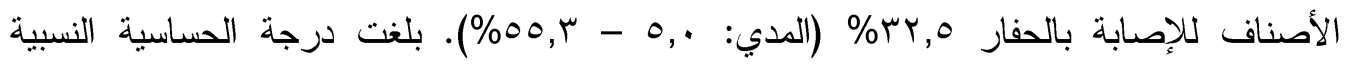

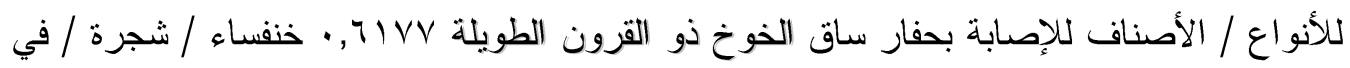

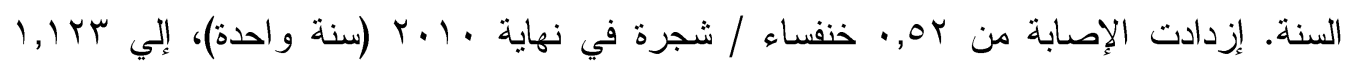

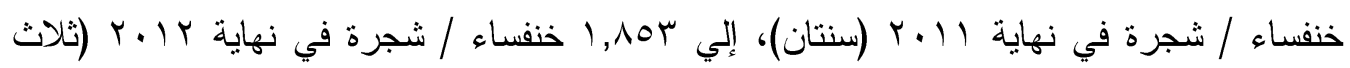

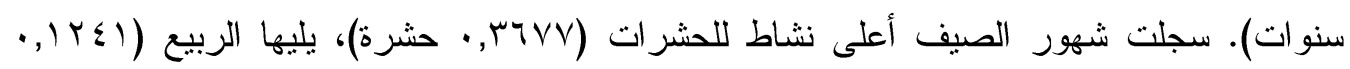

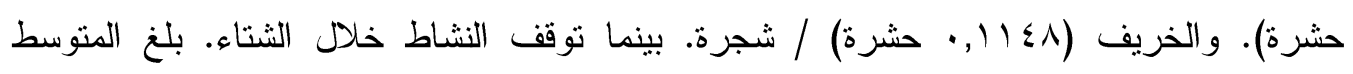

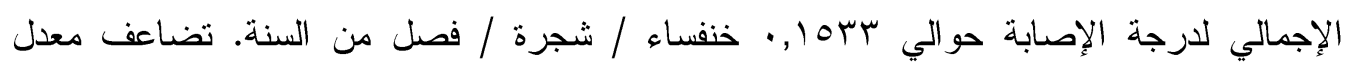

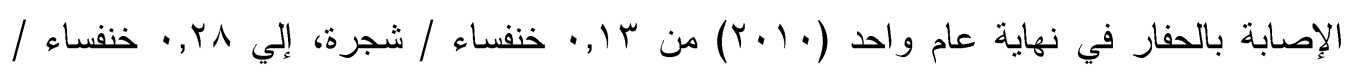

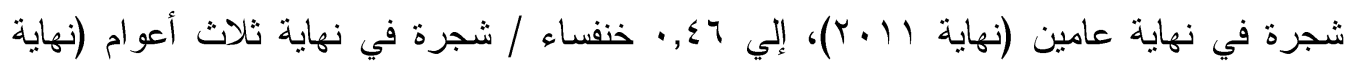

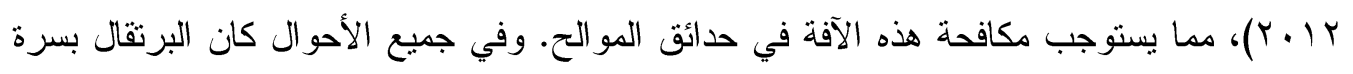

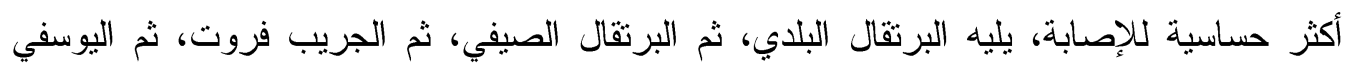

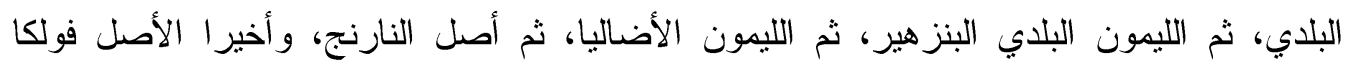

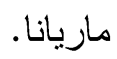

